\title{
ANTIBACTERIAL EFFECT OF RED PIPER BETLE LEAF (PIPER CROCATUM RUIZ AND PAV.) ETHANOLIC EXTRACTS TO LACTOBACILLUS ACIDOPHILUS AND LACTOBACILLUS BIFIDUS GROWTH INHIBITION
}

\author{
SRI AGUNG FITRI KUSUMA*, AMI TJITRARESMI, GITA SUSANTI
}

Department of Pharmaceutical Biology, Faculty of Pharmacy, Universitas Padjadjaran, Indonesia. Email: s.a.f.kusuma@unpad.ac.id Received: 04 November 2016, Revised and accepted: 24 January 2017

\section{ABSTRACT}

Objective: This study was performed to determine the antibacterial concentration of red Piper betle leaf ethanolic extract that is safe for Lactobacillus acidophilus and Lactobacillus bifidus as normal flora of the vagina.

Methods: The phytochemical screening of the ethanolic extract of red $P$. betle leaf was performed using standard procedures. The extracts were tested for determining minimum inhibitory concentration value (MIC) using macrodilution method and minimum bactericidal concentration (MBC) done using the streak plate method. Evaluation of its antibacterial effect to vaginal normal flora growth inhibition was conducted using a plate count method with varying extract concentrations as follows: $0.2,0.4$, and $0.6 \% \mathrm{w} / \mathrm{v}$. L. acidophilus FNCC-0051 and L. bifidus FNCC-0210 were used as tested normal flora vaginal bacteria.

Results: The phytochemical analysis of the red $P$. betle leaf extract revealed the presence of flavonoids, tannin, steroids, saponin, and polyphenolic compounds. The MIC and MBC concentrations of testing extracts against both Lactobacillus ranged from $0.625 \% \mathrm{w} / \mathrm{v}$ to $1.25 \% \mathrm{w} / \mathrm{v}$. The results showed that the extract at $0.2 \% \mathrm{w} / \mathrm{v}$ was the minimum concentration to maintain the presence of Lactobacillus approaching the amount of normal flora in the vaginal ecosystem that is $73-75 \%$. At a concentration of $0.2 \% \mathrm{w} / \mathrm{v}$, it was obtained L. acidophilus survival of $78.43 \%$ while $L$. bifidus amounted to $76.39 \%$.

Conclusion: It can be concluded that the red $P$. betle leaf ethanolic extract is a potential antibacterial and safe for normal flora of the vagina.

Keywords: Red Piper betle, Lactobacillus acidophilus, Lactobacillus bifidus, Survival, Minimum inhibitory concentration.

(c) 2017 The Authors. Published by Innovare Academic Sciences Pvt Ltd. This is an open access article under the CC BY license (http://creativecommons. org/licenses/by/4. 0/) DOI: http://dx.doi.org/10.22159/ajpcr.2017.v10s2.19490

\section{INTRODUCTION}

Women's reproductive health is one of the important parts that should be taken seriously. According to the WHO data, women's reproductive health issues have reached $33 \%$ of all diseases suffered by women. This value is higher than male reproductive health problems, which only reached $12.3 \%$. One of the reproductive problems in women is predominantly fluor albus. According to the International data, $75 \%$ of women had experienced a minimum of fluor albus once in her life [1].

Most women consider fluor albus as a common problem. However, not all discharges are normal condition. In normal vaginal discharge (physiological), its liquid production is influenced by several factors such as hormonal factors, physical exhaustion, and psychological. However, abnormal vaginal discharge (pathological) is usually caused by infection of Neisseria gonorrhoeae bacterium, Candida albicans fungal, and Trichomonas vaginalis protozoan [2]. A research study reported that the prevalence of vaginal infections in women caused by bacteria (38\%), Trichomonas (3.7\%), and Candida (52.5\%) [1]

As a non-specific defense against infectious microorganisms, the normal flora in the vagina available to maintain the balance of the vaginal ecosystem by inhibiting the excessive growth of pathogen microorganisms. In a normal vaginal ecosystem, there is some normal vaginal flora, such as Lactobacillus (73-75\%), Escherichia coli (20-28\%), and Staphylococcus epidermidis (41-57\%) [3-5]. Based on these data, it is known that Lactobacillus is the main normal flora in the vagina.

Physiologically, the increasing of estrogen levels can cause the releasing of epithelial cells, especially in the superficial. The died cells rupture and produce glycogen. The existence of Lactobacillus in the vagina may convert glycogen to lactic acid that protects the vagina from infection with an acidic $\mathrm{pH}$ ranging 4.5-5. Therefore, it is not allowed to change the acidity of the substances that can disturb the pH balance of the vagina [6]. The importance of the normal flora in the vagina causes its existence must be maintained considering that a lot of commercial antiseptics does not pay attention to its effect to the existence of the normal flora in the vagina. Therefore, we need an antiseptic that can kill pathogenic microorganisms but does not disturb the balance of the existing normal vaginal flora.

\section{MATERIALS AND METHODS}

\section{Materials}

The tested plant used in this study is a red Piper betle leaf (Piper crocatum Ruiz and Pav.). Fresh plant materials were collected from Bogor, Indonesia. Plant samples were determined in Plant Taxonomy Laboratory of Biology Major, Faculty of Mathematics and Natural Science, Universitas Padjadjaran.

The tested bacteria used in this study were Lactobacillus acidophilus FNCC-0051 and Lactobacillus bifidus FNCC-0210 obtained from Universitas Gajah Mada, Yogyakarta, Indonesia.

The chemicals used are ethanol 70\% (brataco), de Man Rogosa Shape agar (MRSA-Oxoid) medium and de MRS broth medium (MRSB-Oxoid, London, UK), dimethyl sulfoxide (DMSO-Sigma Aldrich, UK), chloroform (Merck, Germany), mercury (Merck, Germany), ether (Merck, Germany), sulfuric acid (Merck, Germany), amyl alcohol (Merck, Germany), bismuth potassium iodide (Merck, Germany), gelatin (Merck, Germany), iron (III) chloride (Merck, Germany), magnesium powder (Merck, Germany), hydrochloric acid (Merck, Germany), ammonia (Merck, Germany), potassium hydroxide (Merck, Germany), vanillin (Merck, Germany), and aqua dest. 
Preparation of samples

The leaves of red $P$. betle were cleaned and chopped, then dried at room temperature on a laboratory bench, and grounded to a coarse powder using a manual grinder. The powdered material was weighed using an electronic balance. The plant material (300 g) was macerated with $70 \%$ ethanol for 72 hrs successively with intermittent shaking every 2 hrs. The extracts were evaporated using a rotary evaporator at $40-50^{\circ} \mathrm{C}$ and then continued to evaporate on a water bath until dried extract with constant weight was obtained (51.56 g). The extract was stored in a refrigerator at $4{ }^{\circ} \mathrm{C}$ until time of use. The percentage yields $(\mathrm{w} / \mathrm{w})$ of the extracts were calculated using the formula below [7]:

\section{(Weight of extract/weight of starting plant material) $\times 100 \%$}

\section{Phytochemical screening}

The ethanolic extract of the red $P$. betle leaf was subjected to a preliminary phytochemical screening. The phytochemical screening was done using a standard method to determine contain of alkaloids, flavonoids, tannins, quinones, phenolics, saponins, steroids, triterpenoids, monoterpenoids, and sesquiterpenoids in both simplisia and ethanol extracts of $P$. betle leaf [8].

\section{Confirmation of testing bacteria}

Identification of bacteria includes observation of bacterial colony morphology, microscopic observation of bacterial cells consisting of Gram-staining and coloring spores, as well as biochemical test that consists of a test motile and catalase test [9]. The identification was performed according to Bergey's manual of determinative of bacteriology [10].

\section{Gram-staining}

The bacteria colony was examined using the Gram-staining method according to Collins et al. [11]. One dose of bacteria colony was taken and then suspended in sterile normal saline $(0.9 \%)$. One dose of bacterial suspension was swabbed on a sterile glass slide. Microbial swabs were imbued with carbolic gentian violet dye and allowed for 1 minute. Excess dye was dumped and then rinsed with running water. Then, spread microbes were flooded with lugol and allowed for 1 minute. Lugol excess was dumped, washed with $95 \%$ alcohols until the dye dissolves, and then rinsed with water. Then, the smear was flooded by fuchsin and left to stand for 1 minute. Excess dye was dumped, rinsed with water, and then dried using a filter paper. The smear was spilled with oil immersion and then examined under a microscope at a magnification of $\times 1000$. Gramnegative bacterial cell will be red while Gram-positive bacteria in purple.

\section{Spores staining}

Spores staining method were conducted with a standard procedure using different staining reagents. As with the acid-fast stain, heat is required to penetrate the endospore coat. To perform endospore, air tap in beaker glass was boiled on a hot plate. A clean glass slide was obtained and prepared for a bacterial smear. The slide was placed on top of the beaker of water and steam for 5 minutes. Carbol fuchsin was applied on the preparat and allowed to sit for 2-3 minutes. The slide was removed with a clothes pin and placed on the staining tray to cool. The slide was tilted and rinse with distilled water. The slide was covered with methylene blue and allowed to sit for 5 minutes. The slide was tilted and rinsed with distilled water. The slide was dried with filter paper and observed it using oil immersion under a microscope. Endospores will appear as red or clear circles or ovals, whereas vegetative cells will be blue [12].

\section{Catalase test}

To perform this test, a single isolated colony was streaked on a glass slide and one drop of 3\% hydrogen peroxide (Merck, Germany) was added on to it. The effervescence of oxygen indicated the positive response of the bacteria to catalase test [13].

\section{Preparing bacterial suspension}

The bacterial suspension was prepared by transferring a loopful of inoculum into normal saline $(0.9 \%)$ under aseptic conditions from the stock culture maintained at $4^{\circ} \mathrm{C}$. The density of each microbial suspension was adjusted to equal that of $10^{6} \mathrm{CFU} / \mathrm{ml}$ (standardized by 0.5 McFarland standard) [14].

Minimum inhibitory concentration (MIC) and minimum bactericidal concentration (MBC) determination

Determination of MIC of red $P$. betle ethanolic extract was done using macrodilution method. MIC of red $P$. betle against both bacteria was assessed by serial dilution method. The ethanol extracts of red $P$. betle leaf were dissolved in DMSO and then diluted with MRSB medium until achieved concentration as follows: $0.675 \%, 1.25 \%, 2.5 \%$, and $5 \% \mathrm{w} / \mathrm{v}$. The volume of $10 \mu \mathrm{l}$ standardized cell bacterial suspensions was put into each tested concentration. The liquid media were incubated for $20 \mathrm{hrs}$ at temperature $37^{\circ} \mathrm{C}$. MIC was determined from the smallest concentration which did not show any turbidity. MBC was determined from the MIC range using the spread plate method. MRSA media in Petri dishes were subcultured from tubes without growth and incubated at $37^{\circ} \mathrm{C}$ for 24 hrs. The Petri dishes were observed macroscopically. The highest dilution that yielded no bacterial colony on a solid medium was taken as MBC [15].

\section{Calculations of bacterial numbers}

The antibacterial effect of extracts on Lactobacillus growth was observed by calculating the percentage of the surviving bacteria number after contact with the extracts during the incubation period. Type of treatment of tested bacterial cell suspensions can be seen in Table 1.

Each treatment in a test tube was homogenized and diluted to reach $10^{-4}$ dilutions. Each dilution was pipetted to $10 \mu \mathrm{l}$ and dropped on the surface of the MRSA media and then spread using a spreader. The plates were then incubated at temperature $37^{\circ} \mathrm{C}$ for $24 \mathrm{hrs}$. The survival of Lactobacillus colonies was calculated to determine the number of bacterial colonies with and without treatment (L0). The percentage of surviving bacteria (S) was calculated according to the following equation [16]:

$$
\mathrm{S}(\%)=\left(\mathrm{N}-\mathrm{N}_{0}\right) / \mathrm{N}_{0} \times 100
$$

Where:

$\mathrm{N}_{0}=$ Plate count of Lactobacillus without treatments $\mathrm{N}=$ Plate count of Lactobacillus after treatments.

\section{RESULTS AND DISCUSSION}

\section{Yield of the extract}

Extraction method used in this study was maceration method. Maceration was done by immersing the sample in an organic solvent. Organic solvents will penetrate the cell wall and into the cavity of the cell that contains the active substance so that the active substance will dissolve. Due to the difference between the solution concentrations of active substance in the cell, the solution is pushed out [17]. The ethanol leaf extract of $P$. betle yielded $17.18 \% \mathrm{w} / \mathrm{w}$. The characteristic of the extract is brownish green, is sticky, and has a leafy smell.

\section{Phytochemical screening results}

Ethanol extracts of red $P$. betle leaves had shown the presence of flavonoids, polyphenolics, steroids, quinones, and saponins. The result of phytochemical screening can be seen in Table 2. Based on the data in Table 2, it can be seen that in the extracts, simplisia of red betel leaf contains the same compounds. This proves that the extraction

Table 1: Type of treatment

\begin{tabular}{ll}
\hline Type & Treatment \\
\hline L0 & Cell bacterial suspension \\
L1 & $0.2 \% \mathrm{w} / \mathrm{v}$ extracts in cell bacterial suspension \\
L2 & $0.4 \% \mathrm{w} / \mathrm{v}$ extracts in cell bacterial suspension \\
L3 & $0.6 \% \mathrm{w} / \mathrm{v}$ extracts in cell bacterial suspension \\
\hline
\end{tabular}


process which was carried out did not change the content of secondary metabolites present in simplisia.

The secondary metabolites can affect the growth of normal vaginal flora, when formulated as an antiseptic vaginal [18]. This is evidenced in another study which revealed that ethanol extracts of Camellia sinensis is bactericidal against $L$. acidophilus. The presence of major natural chemical groups in the ethanolic extract of $C$. sinensis, such as saponins, flavonoids, phenols, terpenoids, alkaloids, quinones, and steroids, was analyzed [15]. These compounds were detected in the ethanolic extract of red $P$. betle.

\section{Bacterial identification results}

Identification of the bacteria was conducted to determine the level of taxa by comparing the character; it has the character of test bacteria which are known in the literature. The results of the identification of L. acidophilus and L. bifidus can be seen in Table 3.

Bacterial identifications were done by comparing the observations colony morphology, microscopic observation, and biochemical tests with the information contained in the book "Bergey's Manual of Determinative Bacteriology" [10]. The identification results showed that both cells were Lactobacillus species.

\section{The result of MIC and MBC determination}

Red $P$. betle ethanolic extract exhibited antibacterial effect on both of L. acidophilus and L. bifidus. The results can be seen in Figs. 1 and 2 .

From the figures, it can be seen that the MIC of ethanolic extract of red $P$. betle leaf against both test bacteria lies in the concentration

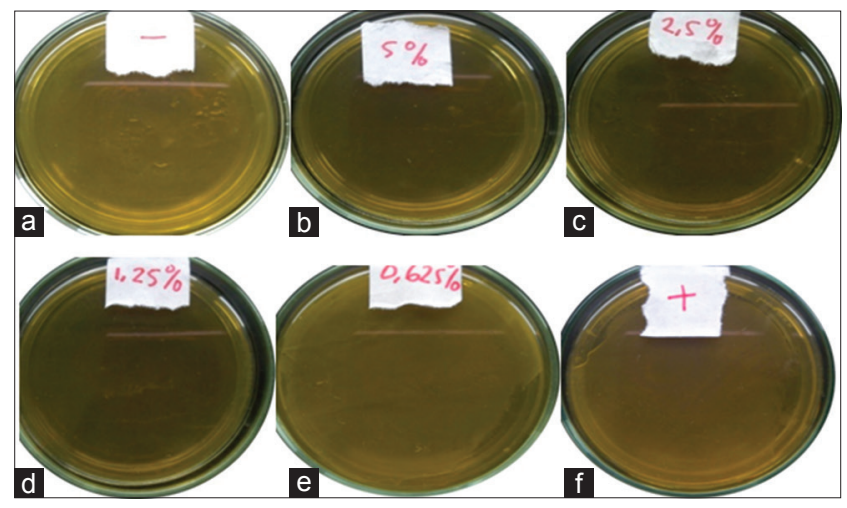

Fig. 1: Growth inhibition of red Piper betle leaf extracts against L. acidophilus. (a) Negative control, concentration of extract in $\% \mathrm{w} / \mathrm{v}(\mathrm{b}=5, \mathrm{c}=2.5, \mathrm{~d}=1.25, \mathrm{e}=0.625)$, (f) positive control

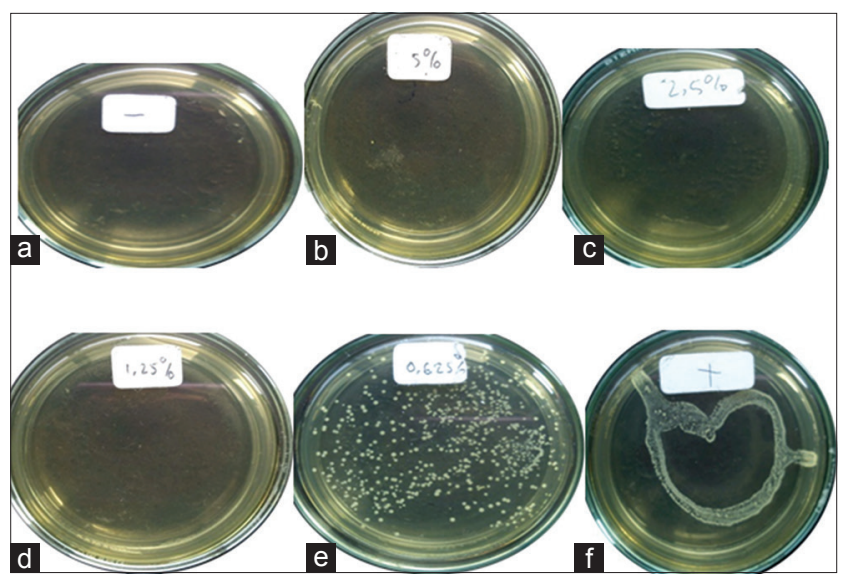

Fig. 2: Growth inhibition of red Piper betle leaf extracts against L. bifidus. (a) Negative control, concentration of extract in $\% \mathrm{w} / \mathrm{v}$ $(b=5, c=2.5, d=1.25, e=0.625)$, (f) positive control of $0.625 \% \mathrm{w} / \mathrm{v}$. The MBC value for both Lactobacillus is $1.25 \% \mathrm{w} / \mathrm{v}$. Another study revealed that MIC of green tea extract on L. acidophilus was found to be $0.3 \%$ and the MBC was found to be $0.9 \%$ [15]. The smaller of MIC and MBC values against Lactobacillus was safer for the growth of Lactobacillus as normal vaginal flora.

\section{The result of bacterial numbers calculation}

Probiotics improves the values of human life since the intestinal tract is a diverse microenvironment where more than 500 species of bacteria thrive. A single layer of epithelium is all that separate these microorganisms and pathogens from the underlying immune cells, and thus, epithelial barrier function is a key component in the defense mechanisms required to prevent infection and inflammation [19].

Vaginitis used to be considered a mere annoyance but now is being examined for a role in serious conditions including pelvic inflammatory disease, pregnancy-related complications, and increased susceptibility to AIDS infection. Vaginitis can be caused by several different organisms, and in many cases, the causative agent may not be identified. What is known is that Lactobacilli predominate in the healthy vagina, and a lack of Lactobacilli is a risk factor for vaginitis [19]. Therefore, Lactobacilli are thought to be maintained in the vaginal ecosystem.

The use of an antiseptic substance concentration should be examined to prevent disruption of the normal vaginal flora. Antibacterial activity of extracts against Lactobacillus will decrease the number of Lactobacillus in the vaginal ecosystem. Therefore, this study was conducted to determine the minimum concentration of red $P$. betle extracts which is safe for the presence of the normal vaginal flora. In a normal vaginal ecosystem, Lactobacillus must remain a minimum of $73-75 \%$ to be able to inhibit the growth of other pathogens [3]. The analysis result of the effects of the extracts on the decreasing percentage of Lactobacillus can be seen in Tables 4-5.

Table 2: Phytochemical screening of extract and simplisia

\begin{tabular}{lll}
\hline Compounds & Extract & Simplisia \\
\hline Alkaloids & - & - \\
Flavonoids & + & + \\
Tannins & - & - \\
Polyphenolics & + & + \\
Saponins & + & + \\
Monoterpenoids sesquiterpenoids & - & - \\
Triterpenoids & - & - \\
Steroids & + & + \\
Quinones & + & + \\
\hline
\end{tabular}

$(+)=$ Present; $(-)$ : Absence

Table 3: Characteristics of tested Lactobacillus

\begin{tabular}{lll}
\hline Criteria & L. acidophillus & L. bifidus \\
\hline Morphology & Opaque, convex & Large round \\
Cell shape & Rod & Rod \\
Gram & + & + \\
Spore & - & - \\
Motility & - & - \\
Catalase & - & - \\
\hline
\end{tabular}

Table 4: The number of colonies of Lactobacillus per $10 \mu \mathrm{l}$

\begin{tabular}{lll}
\hline Treatment & L. acidophillus & L. bifidus \\
\hline 0 & $51 \times 10^{4}$ & $14.4 \times 10^{4}$ \\
1 & $40 \times 10^{4}$ & $11 \times 10^{4}$ \\
2 & $27.9 \times 10^{4}$ & $80 \times 10^{4}$ \\
3 & $17.3 \times 10^{4}$ & $47 \times 10^{4}$ \\
\hline
\end{tabular}

Treatment consists of Lactobacillus suspension with a certain extract concentration $=(0)$ without extract, (1) $2 \% \mathrm{w} / \mathrm{v},(2) 4 \% \mathrm{w} / \mathrm{v}$ and (3) $6 \% \mathrm{w} / \mathrm{v}$. L. acidophilus: Lactobacillus acidophilus, L. bifidus: Lactobacillus bifidus 
Table 5: The effects of extracts on the decreasing percentage of Lactobacillus colonies number

\begin{tabular}{|c|c|c|c|c|}
\hline \multirow[t]{2}{*}{ Treatment } & \multicolumn{2}{|c|}{ Decreasing (\%) } & \multicolumn{2}{|c|}{ Survival (\%) } \\
\hline & LA & LB & LA & LB \\
\hline 0 & 0.00 & 0.00 & 100 & 100 \\
\hline 1 & 21.57 & 23.61 & 78.43 & 76.39 \\
\hline 2 & 45.29 & 44.44 & 54.71 & 55.56 \\
\hline 3 & 66.08 & 67.36 & 33.92 & 32.64 \\
\hline
\end{tabular}

The data indicated that at the maximum concentration of $2 \% \mathrm{w} / \mathrm{v}$, ethanolic extract of red $P$. betle leaf can be used as an active ingredient in the vaginal antiseptic preparation which is safe for normal flora.

\section{CONCLUSION}

It can be concluded that the red $P$. betle leaf ethanolic extract is a potential antibacterial and safe for normal flora of the vagina.

\section{REFERENCES}

1. Seragih DM. Pengalaman Ibu Yang Menderita Keputihan. Sumatera Utara: Fakultas Keperawatan USU; 2009. p. 9-10.

2. Gene BB. Vaginal discharge: Clinical methods. The History, Physical and Laboratory Examinations. $3^{\text {rd }}$ ed. Boston: Butterworth Publishers; 1990.

3. David E, Vagina S, Duenholter DJ. Ginekologi greenhill. Penerjemah: Chandra Sanusi. $10^{\text {th }}$ ed. Jakarta: EGC; 1989.

4. Dorland N. Kamus Kedokteran Dorland. 26 th ed. Jakarta: EGC; 2002. p. 984.

5. Tenney D. Acidophilus. Salt Lake City, UT: Woodland Publishing; 1996. p. 20.

6. Jawetz EJ, Melnick, Adelberg E. Mikrobiologi Kedokteran (Medical
Microbiology). Edisi 20. Translator: Edi Nugroho RF, Maulany. Jakarta: EGC; 1996. p. 192, 290.

7. Onoja SO, Gideon KM, Maxwell IE, Chidiebere C. Investigation of the laxative activity of Operculina turpethum extract in mice. Int J Pathol Clin Res 2015;7(4):275-9.

8. Harborne JB. Phytochemical Methods. $3^{\text {th }}$ ed. New York: Chapman and Hall; 1998. p. 12.

9. Hassan P, Peh KK. Characterization and identification of Lactobacillus acidophilus using biologi rapid identification system. Int J Pharm Pharm Sci 2014;6(1):189-93.

10. Holt G, Krieg N, Sneath P, Staley J, Williams S. Bergey's Manual of Determinative of Bacteriology. $9^{\text {th }}$ ed. USA: Williams and Wilkins; 1994. p. 560-70.

11. Collins CH, Lyne PM, Grange JM. Collins and Lyne's Microbiological Methods. $8^{\text {th }}$ ed. London: Butterworth-Heinemann; 2004

12. Cain D, Hanks H, Weis M, Bottoms C, Lawson J. Microbiology Laboratory Manual. McKinney: Collin County Community College; 2013.

13. Nelson G, George S. Comparison of media for selection and enumeration of mouse fecal flora populations. J Microbiol Methods 1995;22(1):293-300

14. Anupma D, Hemlata S, Sharma RA, Archana SB. Estimation of antioxidant and antibacterial activity of crude extracts of Thevetia peruviana (PERS.) K. schum. Int J Pharm Pharm Sci 2015;7(2):55-9.

15. Anita P, Sivasamy S, Madan Kumar PD, Balan IN, Ethiraj S. In vitro antibacterial activity of Camellia sinensis extract against cariogenic microorganisms. J Basic Clin Pharm 2014;6(1):35-9.

16. Djurdjevic DM, Solaja MM, Topalic LJ, Stijepic MJ, Glusac JR. The survival of Escherichia coli upon exposure to irradiation with noncoherent polychromatic polarized light. Vet Med 2011;56(10):520-7.

17. Cheong WJ. Determination of catechin compounds in Korea green tea influsions under various extraction conditions by high performance liquid chromatography. Bull Korea Chem Sec 2005;26(1):5.

18. Utami P. Buku Pintar Tanaman Obat. Jakarta: Agromedia Pustaka; 2008. p. 228.

19. Praveen KV, Ramya HP, Sri LT. Probiotics: A novel approach in improving the values of human life. Int J Pharm Pharm Sci 2014;6(1):41-3. 